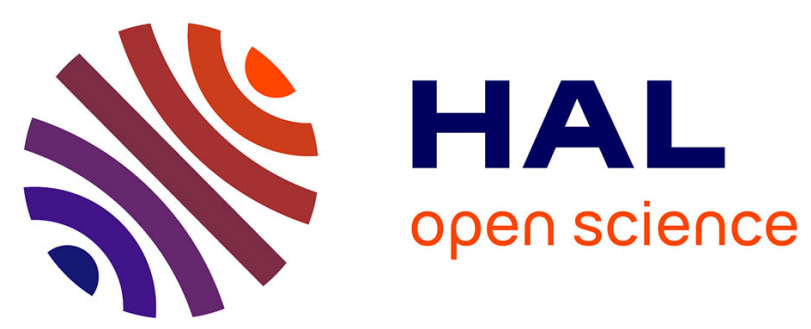

\title{
Avoiding or Accepting Conflict in Public Talk
}

Sophie Duchesne, Florence Haegel

\section{To cite this version:}

Sophie Duchesne, Florence Haegel. Avoiding or Accepting Conflict in Public Talk. British Journal of Political Science, 2007, 37 (1), pp.1-22. 10.1017/S0007123407000014 . hal-01021404

\section{HAL Id: hal-01021404 \\ https://hal-sciencespo.archives-ouvertes.fr/hal-01021404}

Submitted on 9 Jul 2014

HAL is a multi-disciplinary open access archive for the deposit and dissemination of scientific research documents, whether they are published or not. The documents may come from teaching and research institutions in France or abroad, or from public or private research centers.
L'archive ouverte pluridisciplinaire HAL, est destinée au dépôt et à la diffusion de documents scientifiques de niveau recherche, publiés ou non, émanant des établissements d'enseignement et de recherche français ou étrangers, des laboratoires publics ou privés.

\section{(이)(\$)}

Distributed under a Creative Commons Attribution - NonCommercial - NoDerivatives| 4.0 


\section{British Journal of Political Science}

http://journals.cambridge.org/JPS

Additional services for British Journal of Political Science:

Email alerts: $\underline{\text { Click here }}$

Subscriptions: $\underline{\text { Click here }}$

Commercial reprints: Click here

Terms of use : Click here

\section{Avoiding or Accepting Conflict in Public Talk}

SOPHIE DUCHESNE and FLORENCE HAEGEL

British Journal of Political Science / Volume 37 / Issue 01 / January 2007, pp 1 - 22

DOI: 10.1017/S0007123407000014, Published online: 13 December 2006

Link to this article: http://journals.cambridge.org/abstract S0007123407000014

How to cite this article:

SOPHIE DUCHESNE and FLORENCE HAEGEL (2007). Avoiding or Accepting Conflict in Public Talk. British Journal of Political Science, 37, pp 1-22 doi:10.1017/S0007123407000014

Request Permissions : $\underline{\text { Click here }}$ 


\title{
Avoiding or Accepting Conflict in Public Talk
}

\author{
SOPHIE DUCHESNE AND FLORENCE HAEGEL*
}

\begin{abstract}
This article gives an account of experimental research conducted in France with focus groups on delinquency. It is based on theoretical work which shows how the political is partly a mode of expression as well as a way of addressing conflict. An empirical analysis is presented of how people take or resist the risk of conflict in public discussion over social issues. The group discussions corroborate previous insights by attesting that conflict in public discussion is generally latent and often repressed. Specific analysis follows of those processes that contribute to the rare transformation from latent to overt conflict, highlighting the evidence that the public expression of conflict proceeds from participants' alliances and biographical narratives. Moreover, a certain hierarchy of social identification is seen among the participants. The influence of political competence on political implication is complex.
\end{abstract}

Political discussion has long been considered a basic element of any civic culture. ${ }^{1}$ As a mode of political participation, however, it is usually ranked amongst the less influential ones. ${ }^{2}$ Hence, it has been studied less than other types of political participation, such as voting, membership of political organizations or demonstrating, although some stimulating work has been carried out. ${ }^{3}$ This demonstrates how fruitful the study of political discussion is in understanding the complexity of the politicization of citizens in modern democracies. Pamela Conover, Ivor Crewe and Donald Searing, in a recent survey of everyday political discussion published in this Journal, ${ }^{4}$ show that British and American citizens, as self-reported, tend to avoid political discussion outside the protected arena of close acquaintances and family. Their survey, using focus groups, shows that participants indeed greatly distrust the conflicts that can arise from confrontation between points of view.

Indeed, from a theoretical point of view, politics has to do with conflict-based mechanisms, which should not be considered pathological. ${ }^{5}$ The agonistic concept of the political has recently taken centre stage again, following both a critique of Habermas's

* Cevipof (CNRS; and Sciences Po Paris, respectively). This article was translated by Christine Hamidi and Kathy Bramble. The authors are grateful to Elizabeth Frazer and David Goldey, as well as Albert Weale and the anonymous reviewers of the article, who did a great deal in adapting the very French first draft of this article to British standards.

${ }^{1}$ Gabriel A. Almond and Sidney Verba, The Civic Culture: Political Attitudes and Democracy in Five Nations (Princeton, N.J.: Princeton University Press, 1963).

2 Donald D. Searing, Pamela J. Conover, Ivor Crewe and Fred Solt, 'Studying Everyday Talk in the Deliberative System: Does Democratic Discussion Make Better Citizens?' (paper presented at the Conference on 'Empirical Approaches to Deliberative Politics', European University Institute, 2004).

${ }^{3}$ William Gamson, Talking Politics (Cambridge: Cambridge University Press, 1992); Nina Eliasoph, Avoiding Politics: How Americans Produce Apathy in Everyday Life (Cambridge: Cambridge University Press, 1998) and, more recently, Katherine Kramer Walsh, Talking about Politics (Chicago: The University of Chicago Press, 2004).

4 Pamela J. Conover, Donald Searing and Ivor Crewe, 'The Deliberative Potential of Discussion', British Journal of Political Science, 32 (2002), 21-62.

5 Georg Simmel, Conflict and the Web of Group Affiliation (London: The Free Press, 1955). 
theories ${ }^{6}$ and the debate about the deliberative model of democracy. ${ }^{7}$ The agonistic tradition shows how, in complex pluralist unequal societies, the political is in part a mode of expression as well as a way of addressing conflict. Political discussion is, therefore, far from being rational argumentation conducted by free, equal and impartial individuals. Following Carl Schmitt's work, this tradition underlines the specificity of the political, grounded on the logic of inclusion-exclusion and on the possibility of tracing lines of demarcation that separate different categories of people and put them into opposition to each other. ${ }^{8}$ As Carl Schmitt wrote: 'In the domain of the political, people do not face each other as abstractions but as politically interested and politically determined persons, as citizens, governors or governed, politically allied or opponents - in any case, therefore, in political categories'.

The scope and degree of violence in the conflicts that characterize a political system vary greatly. In Western democracies, this form of politicization gives rise to constant and fragile arbitration procedures, so that the word 'conflict' might seem inappropriate. To justify its use, first, let us remind the reader that, in French at least, though the concept of disagreement (désaccord) only refers to the rupture of union, of harmony, or of understanding, the word conflict (conflit) implies that the rupture is fully and publicly acknowledged, that the opposing forces are both organized and identifiable - an essential point when it comes to analysing politics. In the English definition, conflict refers to possible clashes and to the notion of incompatibility. ${ }^{10}$ In other words, the word 'conflict' lays stress on public expression and on the encounter between antagonistic forces in a democratic political community.

At the macro level, emerging conflicts within the political community are supposedly mirrored in party-political and ideological cleavages and come into play in electoral competition before they eventually get resolved through the processes at work in public action. A political community is not only a public sphere, but also a society divided along long-term social and ideological lines. Following a long tradition in political science, we will refer to these lines dividing the political community as 'cleavages'."11

At the micro level, conflict is also at stake in the dynamic of political discussion and more precisely, in the reluctance to express political opinions and commitments. When people discuss, and more particularly when unacquainted people discuss in a public setting,

${ }^{6}$ Chantal Mouffe, The Return of the Political (London: Verso, 1993); Jacques Rancière, La Mésentente (Paris: Galilee, 1995).

7 Amy Gutmann and Dennis Thompson, Democracy and Disagreement (Cambridge, Mass.: Harvard University Press, 1996); Jon Elster, Deliberative Democracy (Cambridge: Cambridge University Press, 1998); Stephen Macedo, Deliberative Politics (Oxford: Oxford University Press, 1999); Bernard Manin, 'On Legitimacy and Political Deliberation', Political Theory, 15 (1987), 338-68.

${ }^{8}$ Carl Schmitt, The Concept of the Political (New Brunswick, N.J.: Rutgers University Press, 1976).

${ }^{9}$ Carl Schmitt, The Crisis of Parliamentary Democracy, trans. Ellen Kennedy (Cambridge: Cambridge University Press, 1985), p. 11, quoted by Chantal Mouffe, 'Carl Schmitt and the Paradox of Liberal Democracy', in Chantal Mouffe, ed., The Challenge of Carl Schmitt (London/New York: Verso, 1999), pp. 38-53, at p. 41.

10 'Conflict fig. Of interests, opinions, statements, feelings, etc.: To come into collision, to clash; to be at variance, be incompatible. (Now the chief sense.)' Oxford English Dictionary.

${ }^{11}$ Stein Rokkan, Citizens, Elections, Parties: Approaches to the Comparative Study of the Processes of Development (Oslo: Universitetsvolaget, 1970); Alan Zuckermann, 'Political Cleavages: A Conceptual and Theoretical Analysis', British Journal of Political Science, 5 (1975), 231-48; Alan Zuckermann, 'New Approaches to Political Cleavages', Comparative Politics, 15 (1982), 131-44; Stefano Bartolini, 'La Formation des clivages', Revue internationale de politique comparée, 12 (2005), 9-34. 
points of disagreement may occur between group members that are not just occasional, anecdotal and personal oppositions, but overlap with the conflicts within society at large. That is why we will use the same term 'cleavage' to refer to the main lines of conflict in the group discussion. While giving his or her opinion, a participant also says where he or she is regarding to a specific cleavage, and takes the risk of acknowledging that he or she does not belong to the same side as the others.

In this research, we have thus adopted a specific angle of observation of political discussion: we observe how participants take or resist the risk of conflict in a discussion over a social issue and expect from it a different understanding of the individual process of politicization. This article aims to take stock of our findings so far. ${ }^{12}$ It is designed to draw lessons from the analysis of three experimental focus groups organized in France on the topic of delinquency, prior to organizing additional groups and adding a comparative dimension. In the first section, we present the research design and explain our main methodological choices. In the second section, we present the main results of the study: while the discussions do reveal latent conflict, overt conflict is very rare. In the third and last section, we analyse conflict mechanisms revealed by the discussion: the interweaving of the individual and the collective through alliances and biographical narratives; the hierarchy of identification; the complex effect of political competence.

\section{RESEARCH DESIGN: DISCUSSION GROUPS FOCUSING ON DELINQUENCY}

The practical difficulties of observing and recording informal everyday talk are quite considerable. We use focus groups instead, since they allow us to observe what matters most to us: the exchange of viewpoints in a collective, public and interactive setting, where disagreement can be expressed. These focus groups were recruited, conducted and analysed according to specific methodological choices.

\section{Recruitment}

The technique of focus groups and other discussion groups is less widely used in France than in English-speaking countries. ${ }^{13}$ These focus groups were arranged according to a well-tried method so as to gather people with fairly similar social profiles, in an attempt to mitigate the effects of the underlying inequalities in people's relation to public discourse. Homogeneity is frequently sought through groups made up of previously acquainted people, as in Gamson's work; ${ }^{14}$ failing that, one or two simple criteria are selected that are supposed to define the social profile of the participants. The criteria were selected to ensure homogeneity in the type of job held by each participant, or rather the type of job aspired to, since the participants were all contacted through an employment exchange. Chronologically, the first group consisted of unskilled workers; the second group was

12 Sophie Duchesne and Florence Haegel, 'Entretiens dans la cité, ou comment la parole se politise', EspacesTempsLesCahiers, 76/77 (2001), 95-109. Sophie Duchesne, Florence Haegel et al., 'Politisation et conflictualisation: de la compétence à l'implication', in Pascal Perrineau, ed., Le Désenchantement démocratique (La Tour d'Aigue: Les Editions de l'Aube, 2003); Sophie Duchesne and Florence Haegel, L'Enquête et ses méthodes: Les entretiens collectifs (Paris: Nathan (collection 128), 2004).

13 David L. Morgan, Focus Groups as Qualitative Research, Qualitative Research Methods Series v. 16 (Thousand Oaks, Calif.: Sage, 1997); Duchesne and Haegel, L'Enquête et ses méthodes.

14 Gamson, Talking Politics. 
composed of managers, and the third one of office workers. The socio-professional homogeneity of the various groups turned out to be relative; we shall come back to that later. Furthermore, the groups were heterogeneous according to other criteria, such as age, gender or political orientations, among other things. A characteristic of these groups that played an important role in the dynamics of conflict was the variation in the ethnic origins of the participants. Although it conforms to the current multicultural society of France, this heterogeneity is rarely so clearly represented in a survey.

\section{Group of unskilled workers}

Nacer: Egyptian citizen; living in France since 1992; no religion; slightly interested in politics; will not disclose his political orientations.

Khaled: French citizen; no religion; 'slightly' interested in politics; politically, neither right-wing nor left-wing.

Kassam: French citizen; a practising Muslim; not at all interested in politics; politically, neither right-wing nor left-wing.

Mansour: Malian citizen; living in France since 1989; a practising Muslim; keenly interested in politics; a left-winger (he declares that he is a Communist).

Gérard: French citizen; not at all interested in politics; politically, neither right-wing nor left-wing.

Manuel: French citizen; not at all interested in politics; no political orientation.

\section{Group of managers}

Jordan: French citizen; born in the West Indies; has been living in metropolitan France since 1972; a non-practising Catholic; keenly interested in politics. Political orientation: 'My friends regard me as a right-winger. I think our politicians should be retired and replaced by younger men in their late 20 s or early 30 s. And the retirement age should be set at 70.'

Aline: French citizen; a non-practising Catholic; slightly interested in politics; leans towards the left.

Jessica: French citizen; a non-practising Protestant; slightly interested in politics; leans towards the left.

Faiz: French citizen; born in Chad; a practising Protestant (his father is a minister); keenly interested in politics; politically, a left-winger.

Coline: French citizen of West Indian descent; a Catholic; keenly interested in politics; leans towards the left.

Guillaume: French citizen; has no religion; keenly interested in politics; politically, a left-winger.

François: French citizen; a non-practising Catholic; keenly interested in politics; politically, a left-winger.

\section{Group of office workers}

Tarek: French citizen, born in Algeria; will not disclose whether he has a religion or not; keenly interested in politics; leans towards the left.

Jean-Claude: French citizen; he will not disclose whether he has a religion or not; keenly interested in politics; refuses to disclose his political orientation.

Hassen: French citizen; born in Tunisia; non-practising Muslim; not at all interested in 
politics (but proclaims that he is knowledgeable about political matters), neither right-wing nor left-wing.

Farouk: Moroccan citizen; non-practising Muslim; slightly interested in politics. About his political orientation, writes, 'As I see it, all parties are pretty much alike.'

Monique: French citizen; non-practising Catholic; keenly interested in politics; politically, a right-winger.

Marie: French citizen; regular church-goer (has not specified her religion); slightly interested in politics. Refuses to disclose her political orientations (after Jean-Claude has publicly refused to disclose his).

Christiane: French citizen; non-practising Catholic; slightly interested in politics; leans towards the left.

We chose to recruit previously unacquainted people. Those who took part in the focus group discussions had never met before; we wanted them to feel as if they were taking part in a public debate. But because they were not acquainted, it was important that the discussion lasted long enough for them to become accustomed to each other's ideas and positions. Allowing plenty of time for the discussions (three hours) permited us to really observe the participants' mixed feelings and tensions, as well as the changes in their viewpoints. These variations can be grasped within the context of the social interactions born from discussion, thus taking account of the social relations between the participants, particularly their influence-strategies and the effects of self-censorship.

Choosing to contact people through an employment exchange and to pay them for their participation, we aimed to recruit a type of person who rarely features in surveys. In this particular instance, French scientific tradition differs widely from British or American practice. In France, paying interviewees is generally regarded as something that should be reserved for commercial polling, on the grounds that private gain may bias people's answers. But we consider that the motivations inducing people to give some of their time and to air their views to some anonymous surveying team are even more likely to bias their answers. In fact, selecting interviewees from among job-seekers allowed us to make up groups in which ethnic minorities were well represented and in which discursive and political competence varied widely. This did, however, bias the participants in an unprecedented, at times embarrassing, way. Some of them tended to mistake a focus group discussion for a job interview. This was particularly the case among the executives, as the discussion was offering them an opportunity to give evidence of their capacity to work together. ${ }^{15}$ For all that, the main weakness in our research design lies in the limited number of focus groups. As each socio-professional group is represented by one focus group only, we tend to ascribe all the differences between the groups to this single variable, when many of them may equally be accounted for by other factors, including group dynamics.

This research was first designed as experimental. The very small number of focus groups actually did facilitate the analysis of processes. This article presents the hypotheses taken from this experimentation that we are currently testing on a larger scale. ${ }^{16} \mathrm{We}$ are aware of the limited transferability of our results so far. However, it must be noted that the content of the discussion and especially the main cleavages that were revealed by the dynamics

\footnotetext{
15 Jordan even left us his curriculum vitae.

16 'How Discussion Becomes Political', a comparative research programme involving Elizabeth Frazer (New College, Oxford), André-Paul Frognier (University of Louvain-la-Neuve, Belgium) and the authors, funded by the French Ministry of Research, Sciences Po Paris, the Leverhulme Trust and the Belgian FNRS.
} 
of conflict indeed corresponded, to a large extent, to those that emerge from extensive quantitative surveys.

\section{Organization of Discussion}

The topic to be discussed was not revealed beforehand. The participants were asked to discuss delinquency, a controversial topic which we had chosen because it offers a lot of advantages for testing a conflict-based analysis of public discussion. It occupies centre stage in the French political scene: one year after we had organized our focus groups, law-and-order became the central issue in the 2002 presidential campaign. ${ }^{17}$ In addition, this topic is dealt with by a sufficiently wide range of players to be likely to be of interest to a lot of people without any particular competence or experience in the matter. Another requirement was that the topic offered could be politicized during the discussion to various degrees and in different ways. And indeed it enabled us to observe different expressions of politicization, ranging from 'Immigrants are to blame for the rise in delinquency', to 'Unemployment breeds delinquency', to 'Parents no longer do their job, there are too many broken families', to 'It's a matter of values', etc.

An important aspect of our focus groups is the method we adopted to facilitate discussions. Our facilitation method was adapted from that developed by Metaplan ${ }$, a German consultancy. Facilitation consists in recording the views of the participants, as they are being expressed, on flipcharts, so that they can reflect upon and react to what they have been saying. The crucial characteristic of this method is that it encourages people to express dissent. The facilitator expressly invites participants' reactions, urging them to express any form of hesitation about what she is recording - be it incomprehension, a desire for a change in wording, for greater precision, and above all, dissent. It gives to the expression of dissent a less dramatic, even playful dimension. Every time a participant voices reservations about the way a point has been recorded, a 'flashmark' is made next to the relevant sentence, which is specifically discussed at the end of the session. This discussion focuses on the expression of dissent. This so-called 'flashmarking' procedure ${ }^{18}$ is laid down as a basic rule of the game and gives rise, particularly at the beginning, to a great many jokes, which helps allay the nervousness of the participants. Instructions are given to the moderator to suggest flashmarks during the first question in order for the participants to get used to it.

The original moderation technique is far from being a laissez-faire approach, it is meant to keep the discussion under strict control. The facilitator plays a very central role. Even though he constantly asks the group for confirmation, he is the one who writes down and therefore selects the views that will be recorded. However, we adapted the technique for our research purposes. We found that too much control prevents the expression of conflict. Moreover, we had originally been trained as 'non-directive' interviewers. ${ }^{19}$ As a consequence, we adapted the moderation technique in two ways. First, the original method aims at recording a large range of opinions in order to find the space available for consensus or decision, but does not look for going in greater depth into the opinions expressed. We introduced some degree of in-depth listening and have tended to write on the board as

17 Jacques Gerstlé, 'Une Fenêtre d'opportunité électorale', in Pascal Perrineau and Colette Ysmal, eds, Le Vote de tous les refus (Paris: Presses de Sciences-Po, 2003), pp. 29-52.

18 There are three rules of the game that are formally laid down at the onset of the discussion: 'Speaking-time must not exceed thirty seconds', 'Everything must be discussed in writing', 'Dissent must be noted with a mark'.

${ }^{19}$ Carl Rogers, 'The Non-Directive Method as a Technique for Social Research', American Journal of Sociology, 50 (1945), 279-89. 
extensively as possible what was said by participants instead of selecting the most interesting topic for the group dynamic. Secondly, although we recorded systematically all disagreements, we did not get the group to confront them as much as a professional moderator would have done. We found that displaying too much conflict generates defensive or avoidance strategies. Once the moderator knew the participants were aware of the main disagreements between them, she would let them handle these in their own way. ${ }^{20}$ Hence the balance between control and laissez-faire changes according to the dynamics of the discussion. It is more controlled in the beginning, in order to get the group established.

The moderation technique has one final specificity; it also includes the preparation of a scenario. A scenario displays a range of topics, and elicits different modes of answers, individually or in subgroups, alternating open questions, contradictory arguments, role playing, voting (see the Appendix for the scenario used in this research project, which gives an idea of the possible variations). The variety of questions helps to channel the dynamics of conflict acknowledgement.

Analysis

All the sessions were both audio-taped and video-taped. Videotapes constitute the chief material for the analysis, but they are supplemented by the sheets of paper recording the main points of the discussions, as well as by the observer's notes - a research assistant having made a manual record all the way through the discussion. Once the data have been collected, the next step is to determine how they are going to be analysed, what is going to be subjected to observation and interpretation, and what results will eventually emerge. Considering that the design of the research was meant to be experimental, we did not proceed to a systematic coding of the corpus: we thought the sample would not allow us to do any kind of statistically significant analysis of what had actually been said during the discussions. We choose to focus the analysis on some specific points of the discussions. Following the agonistic theory of politics, we have selected the moments when the participants hesitated to take the risk of explicitly disagreeing - about ideas, interests or values - with their interlocutors. These 'sensitive moments' are clearly perceptible in the dynamics of discussion, when individuals obviously hesitate explicitly to advance an opinion which is likely to result in open conflict with the others. ${ }^{21}$ Antagonistic viewpoints are then expressed and are related to pre-existing cleavages, so that opposing sides become visible. In fact, these sensitive moments are not only moments of revelation, when the cleavages become explicit. They are mainly moments of avoidance, when conflicts are defused, for, from our observation, it appears that in most cases, potentially conflicting social interactions eventually get defused.

Empirically, the points at which conflict occurs can of course be identified from what is being said, but also from the changes in inflection or pace of speech, or from an amplification of body language - the participants moving closer to, or away from the centre point of the discussion as well as each other. The greatest merit of the focus-group technique is that it enables us to grasp what is going on at group level, as well as the

20 The 'she' here reflects the fact that the moderator was a woman in each case.

21 Jenny Kitzinger and Clare Farquhar, 'The Analytical Potential of Sensitive Moments in Focus Group Discussions', in R. S. Barbour and J. Kitzinger, eds, Developing Focus Group Research: Politics, Theory and Practice (London: Sage, 1999), pp. 156-72. 
individual position of each participant, simultaneously and with equal clarity. ${ }^{22}$ Our analysis of how people avoid or accept conflict in public discussion takes into consideration both levels. We observe the individual involvement of participants in the discussion and try to find out how and why each of them individually gets involved or not in a specific exchange, at a specific point. But we also take into account to what extent a specific conflict establishes itself in the group and involves many of the participants. We thus analyse how a latent conflict may turn into an open one.

\section{CONFLICT IN PUBLIC DISCUSSION IS GENERALLY LATENT AND OFTEN DEFUSED}

Analysing these group discussions by looking for conflict involves working on mere traces, for one of the first findings of the experimental work is that open conflict is a rare occurrence. Pamela Conover and her colleagues also reported that one of the reasons given by British and American focus-group participants for avoiding political discussions was the private character of their opinions. ${ }^{23}$ They claim that anyone has the right to hold his/her own opinions and not to have to justify or defend them in public. Indeed, in our groups we did observe the tension that participants experienced between wanting to protect the private character of their own opinions and the desire to reveal them to others in confronting their views. Basically, the dynamics of public discussion depends on the way the participants assume the risk of engaging in conflict with persons who are more or less strangers. It depends on how far participants feel authorized to or confident enough to take such a risk; we will come back to that shortly. But it also presupposes that they are able - however imperfectly - to perceive and evaluate the risk that their opinion may give rise to a conflict. And this implies that they have accurately decoded the implications of the views which are being exchanged.

\section{Conflict Latent in the Confusion of Ordinary Talk}

In many cases, the points of disagreement are not acknowledged as such: they are left unsaid because ordinary talk is basically disorganized. We have observed in these groups, particularly in the early stages of the discussion, that a lot of potential conflicts simply remain latent, dissolved in the free flow of a conversation where sentences follow on one another and ideas are juxtaposed, without anyone making any connection between them. Let us look at a first example, taken from the office workers' discussion. They were asked to work in groups and complete a story about delinquency (see interview guide in the Appendix). One of the stories they wrote told of children who stole clothes in a supermarket, while the other customers watched them without concern. The authors of this

\footnotetext{
22 The debate over the relevant level of analysis of the focus group is an essential one. In contrast to the early days of experimental research, when focus groups were used for economy of scale and also to encourage the expression of certain opinions (see R. K. Merton with M. Fiske and P. L. Kendall, The Focused Interview: A Manual of Problems and Procedures (New York: The Free Press, 1990 [1956])), some have gone so far as to argue that the relevant level can only be that of the group, as do B. F. Crabtree, M. K. Yanoshik, W. L. Miller and P. J. O'Connor, 'Selecting Individual or Group Interviews', in D. L. Morgan, ed., Successful Focus Groups: Advancing the State of the Art (Newbury Park, Calif.: Sage, 1993), pp.137-49. Our view is that playing on both levels is more efficient, both to make sure that the material is dependable (an argument also put forward by M. A. Carey and M. W. Smith, 'Capturing the Group Effect in Focus Group: A Special Concern in Analysis', Qualitative Health Research, 4 (1994), 123-7), and, as this article should make clear, to make the most of the method.

${ }^{23}$ Conover, Searing and Crewe, 'The Deliberative Potential of Discussion', pp. 54-5.
} 
story insisted that the children did not believe they would be punished, on the escalation of events being at the core of delinquency and, hence, on the responsibility of adults in the matter. They called the story 'who steals an egg steals an ox' (a French saying equivalent to 'You may as well be hanged for a sheep as for a lamb'). Tarek presented the story on behalf of the group because it was based on a true story, in which he had taken part. Telling about his own behaviour, he kept saying that he was purely a spectator, that he was there by chance, waiting for his wife, and that he was just amazed by the lack of concern shown by the by-standers. The discussion went on for a while, in quite a lively fashion; nobody ever commented on Tarek's possible contradiction between his evaluation of other people's behaviour and his own.

Our interpretation is that the collective silence on Tarek's own responsibility was not just a way of avoiding putting him on the spot - 'face-work' as Goffman calls it. ${ }^{24}$ A detailed analysis of the conversation shows that the participants did not see the contradiction. To emphasize the effect of the disorganization of ordinary talk, let us consider a second example, taken from the discussion between the unskilled workers. All the participants were looking at the facilitator intently, eager to put in a word, each one asserting his own view as if it backed up the previously stated one.

\section{Extract 1 (Unskilled workers): 'Parents abdicate responsibility'}

MANSOUR: I had also said it's because they won't let us raise our kids as we wish. They take our children into care.

KHALED: What they [meaning parents and children] need to do is talk.

MANUEL: They are just plain irresponsible. What they need is a kick up the arse. Some parents have ... too many problems on their own hands, so they don't look after their children.

MANSOUR: The real problem is that it prevents them from doing as they see fit with their kids. No parent is going to tell his child to go and hold up a bank. They are afraid of losing their kids.

KHALED: They simply abdicate all responsibility for their children!

Three very different views about the relations between parents, children and society are expressed in this sequence. Mansour, who was born in Mali, wishes parents were allowed to bring up their children as they wish, using corporal punishment according to African tradition if necessary, which contravenes French law forbidding ill treatment of children. Khaled, born in France and of Algerian descent, holds the view that parents do not talk enough with their children; and Manuel, for his part, feels that too many parents prefer to look after themselves rather than pay heed to the problems with which their children may be confronted. These various viewpoints are potentially antagonistic, since they reflect different attitudes towards and perhaps experiences of the exercise of authority, but the participants do not seem to be aware of this. In fact, this way of carrying on a discussion is by no means exceptional, since, in ordinary conversation, viewpoints are often exchanged without any logical connection between them being established and without their potential for contradiction, disagreement or conflict being acknowledged. As Lynn Sanders rightly stated in her article 'Against Deliberation', ${ }^{25}$ contrary to the expectations of the deliberative model, everyday talk is neither rational nor orientated towards a common topic of discussion. Public expression of conflict presupposes that participants decode the consequences of the views they are exchanging with the other members of their

${ }^{24}$ Erving Goffman, Interaction Ritual: Essays on Face-To-Face Behaviour (New York: Pantheon, 1982).
${ }^{25}$ Lynn M Sanders, 'Against Deliberation', Political Theory, 25 (1997), 347-76. 
focus group. The nature of the discussion needs to be appropriate, a condition far from always realised in the group discussions.

\section{Conflict Dissolved by Cognitive Competence}

In order to decode the potential conflict, participants must have the cognitive ability to do so. But cognitive skills have various effects. They supply the resources needed to spot contradictions or inconsistencies but, paradoxically, they may also have a dissolving effect on conflict. Thus the 'learned' stance adopted by the group of managers induced them from the outset to try to come up with a definition of delinquency, not using examples as a starting-point, but discussing criteria which might define the scope of the phenomenon: age, premeditation, the unlawfulness of the acts under consideration, etc. Faiz (we will come back to him later) was the only one who insisted on stopping that game ('This is getting us nowhere'). He attempted to make the other participants acknowledge that delinquency is usually blamed on young second-generation immigrants and hence to address the political debate related to delinquency. It was clear, however, that nobody else was prepared to engage in a potentially conflictual debate about immigration.

Conversely, there is the example of the group of unskilled workers, a group actually largely composed of young second-generation immigrants among whom unemployment is particularly high. They were used to being regarded as delinquents - so much so that some of them clearly suspected the researchers of having chosen that particular topic just to confound them. Their discussion revolved from the start around the causes of and the responsibilities for delinquency and the way it is dealt with. From the outset, they offered a hotchpotch of major explanatory factors: unemployment, restrictions of freedom of expression and children's upbringing, as well as the corruption of politicians and discrimination, giving the discussion a definitely overt conflictual turn.

The experience of these two focus groups highlights the reluctance to simplify and the taste for sophistication of the managers, who displayed more highly developed cognitive skills, which prevent conflict. By contrast, the unskilled workers' relative lack thereof induced them to express views structured along an overtly acknowledged cleavage. ${ }^{26}$

\section{Conflict Repressed Because It Involves Taking a Risk}

Since getting involved in a discussion means taking the risk of engaging in conflict, one also has to feel authorized to do so. This feeling of legitimacy is not evenly distributed in society. This could support the general point made by Sanders against deliberation: the fundamental inequality of participants in discussion is a direct consequence of the fundamental inequalities of social relationships. ${ }^{27} \mathrm{~A}$ number of empirical elements corroborate this. For example, in the group of office workers, gender inequalities are clearly visible (in contrast to the all-male group of unskilled workers). Two of the female participants, holding the most menial jobs within that group, stayed in the background practically throughout the session. But we know that they share the views of Jean-Claude,

\footnotetext{
${ }^{26}$ Furthermore, as we said before, the situation, very similar for the executives to some kind of job interview, promoted a tendency towards co-operation that is not a good basis for the expression of conflict. This kind of discussion was obviously totally unfamiliar to the unskilled workers. They could not confuse it with a professional test where their capacity to collaborate would be required.

27 Sanders, 'Against Deliberation', pp. 363-5.
} 
one of the most talkative male participants. They acquiesce by nodding their heads or glancing at him when he speaks. Instead of getting involved and joining forces with him to engage in conflict with the other participants, they remained silent, contributing to the session's definite tone of repressed conflict.

We know from interactionist work that public everyday talk does not promote the expression of disagreement. ${ }^{28}$ Indeed, in these groups, participants avoid openly expressing disagreement with one another and open conflict rarely happens. Conflict is either latent or repressed. However, some sequences of the discussion are obviously 'sensitive moments' where the talk becomes uneasy and the tension between the participants tangible. In the next section, we present the different processes which contribute to this rare transformation from latent to overt conflict.

\section{THE PROCESSES OF CONVERTING LATENT TO OVERT CONFLICT}

In this section, we will consider four elements that intervene in the difficult process of turning a latent into an overt conflict. The first two elements refer to what happens during the discussion itself: first, the making of alliances between participants; secondly, the use of biographical narratives as arguments at the point of personal involvement in group conflict. The third element is deduced from the attitudes of the participants who contribute the most to the overt expression of conflict in the group: getting involved in such conflicts seems to require a certain hierarchy of one's social and ideological identifications. Lastly, we briefly examine the complex influence of political competence on the way conflict is expressed in public discussion.

\section{Conflict is Fuelled by Alliances Between Participants}

Michael Billig reminds us that when voicing opinions in a real-life situation, you have to mobilize a dual reference system referring both to the subjects broached and to the people you are exchanging views with. He shows how in group discussions between close friends or relations (family members, friends or neighbours), the stance each participant assumes in relation to others does as much to explain the views he expresses as their substance. ${ }^{29}$ Billig rests his demonstration (amongst other things) on the previously existing relations between the group members. We observe the same impact of the relationship between participants on the views they express in our own research, although the design is different in that we have brought complete strangers together. Participants do not commit themselves in acknowledging disagreement from the beginning: they need some time to identify the people with whom they are exchanging views. ${ }^{30}$ In these groups, voicing personal opinions, instead of reviving well-known differences and similarities and replicating domestic hierarchies, proceeds from risk-taking. Hence, the different processes which facilitate this may be analysed as personal resources.

The acceptance or avoidance of conflict does not follow an alternating sequential pattern; in most cases, they are intertwined; they are characterized by aborted attempts

\footnotetext{
28 Goffman, Interaction Ritual; Eliasoph, Avoiding Politics.

${ }^{29}$ Michael Billig, Ideology and Opinions: Studies in Rhetorical Psychology (London: Sage, 1991), chap. 8, pp. 168-94.

30 That is the reason why we organize the discussion in two sessions separated by a break. Refreshments are provided. In some ways, the informal discussion during the break gives participants the opportunity to become acquainted with some others.
} 
at expressing conflict; they proceed by fits and starts, with sudden outbursts that soon peter out. ${ }^{31}$ The erratic nature of this process is due to the way it works. In practice, in these groups, conflict emerges clearly when at least two persons engage with each other against the rest of the group. In a group of strangers, the fact that no one knows for certain what truly matters to others makes this process uncertain and erratic. The risk lies in the choice of the alliance as much as in the choice of the opponents.

This does not mean that an individual participant will not risk voicing an opinion on his or her own which not only clashes with others but conflicts with them in such a way that a cleavage would be summoned up. Boltanski and Thevenot's work suggests that in such a case, the lonely protester would refer implicitly to a supportive group, possibly an abstract one, by some kind of generalization of his arguments. ${ }^{32}$ However, that did not happen in our groups. The following extract exemplifies how, as long as no alliance has been concluded between two or more participants, conflict remains latent. The exchange is taking place between the office workers, towards the end of the session, at a moment when all the participants are fully aware of each other's positions, and a covert hostility has been brewing between Jean-Claude and the participants of North African origin. Hassen, a man of Tunisian origin, takes advantage of an innocuous remark passed by Jean-Claude to add fuel to the fire; but in keeping with his attitude throughout the session, ${ }^{33}$ he immediately withdraws from the interaction. Farouk, who is of Moroccan origin, is left alone to go on unveiling the cleavage between them and Jean-Claude. He does not get any backing from Tarek - who is also of North African (Algerian) descent - who is, on the contrary, intent on avoiding conflict. For his part, Jean-Claude does not get any support from the female participants, and yet their behaviour all through the session suggests that they actually share his views.

\section{Extract 2 (Group of office workers): 'Who are the French?' \\ Jean-Claude is commenting on the stereotype: the French are an undisciplined people.}

HASSEN: Who are the French?

JEAN-CLAUDE: The French lack discipline in many areas, a very wide range indeed.

FAROUK [addressing Hassen with a half-smile]: The French are your dad, his dad ... his grandfather!

HASSEN: Well, my grandfather did not live in France and he did well not to.

FACILITATOR [summing up]: Hassen, 'Who are the French?'

TAREK: Why, all those who live in France, I mean, we are not going to ... us in fact. [silence] No matter where they come from.

FACILITATOR [reading aloud from the flipchart]: So here, 'Who are the French?' then, 'It is us' 'Those who live in France?' [silence]

TAREK: Well, as for me ...

JEAN-CLAUDE [interrupting him]: No, according to me, they are those who must abide by French law...

\footnotetext{
${ }^{31}$ It will be noted that our observation clearly disproves our previous assumption that the process of assuming conflict is a gradual one, which among other things, includes broadening one's outlook and acknowledging a cleavage prior to getting involved (Duchesne and Haegel, 'Entretiens dans la cité', p. 99).

${ }^{32}$ Luc Boltanski and Laurent Thevenot, De la Justification: Les economies de la grandeur (Paris: Galllimard, 1991).

${ }^{33}$ An attitude which may be accounted for by the fact that, in his opinion, he does not belong in this group. Although he has held only menial positions, his advanced degrees had marked him for executive jobs. As a matter of fact, he had originally been selected to join the group of managers, but as a greater number of people volunteered to join this group, he was ultimately assigned to the group of office-workers and he is cognizant of the fact.
} 
TAREK [interrupting him in turn]: Personally, I would say they are those who love France. According to me, the French are those who love France. If you don't love France, you can't even begin to be French.

FACILITATOR [summing up]: They are those who love France, those who have to abide by the law, is that correct?

JEAN-CLAUDE [intent on driving the point home]: French law.

FAROUK [with a half-smile]: In that case, people who have obtained French citizenship, but don't abide by French law, are not French then? If I hear you right ...

MARIE: No, no!

JEAN-CLAUDE: No, no. Be they English or Indian, if they are on French territory, they have to respect French law, whatever they do.

FAROUK: Ah, all right.

JEAN-CLAUDE: Whatever their nationality by birth.

FAROUK: So, even if ... [but he smiles and does not complete his sentence]

This sequence features all the elements that might lead to the overt expression of the cleavage along which the group has been structuring itself for almost three hours, pitting the French by birth against the participants of North African origin. The faults in Jean-Claude's line of reasoning are quite blatant, and Farouk could quite easily point them out and indeed make the man look ridiculous in the eyes of the female participants, provided that Hassen and Tarek were prepared to support him. But Hassen zones out and remains silent, whereas Tarek devotes all his energies to reaching a form of consensus. By contrast, in the lengthy extract that follows next, we can observe a sequence leading to almost full-blown conflict, in which a system of reinforcement and mutual backing is clearly at work.

\section{Conflict Is Fed on Exemplary Biographical Narratives}

The exchange takes place among the managers, who are discussing the advantages and drawbacks of the welfare state. Jordan, Coline and Faiz are all of African or West Indian descent. The starting-point of the discussion was a mark drawn beside the sentence 'No future'. Jordan, who grew up in Seine-St-Denis, in a deprived housing estate in the suburbs of Paris, tells the others about his life in an area where "no civil servant wants to live and work'. He explains how he 'pulled himself together and did well at school' instead of 'feeling rebellious'. Jessica mainly, but to a certain extent Guillaume as well, react sarcastically to Jordan's biographical story. As long as Jordan was the only one to offer himself as a paragon for individual responsibility, it is easy for the other participants to ridicule him, and to use his life history to get back at him. But when Coline passes a remark that adds grist to his mill, she ignites the latent conflict. Faiz henceforth sides against them, strongly justifying the welfare state. It remains unclear whether their common African origins had previously restrained Faiz or further infuriated him.

Extract 3 (Group of managers): 'No one takes control of their own lives anymore.' [The facilitator wants to know who asked for a mark to be made beside the phrase 'No future'. This immediately sparks a heated debate during which Jordan tells about his own life.]

JESSICA: Have you always had the feeling that you did not have a good future?

GUILLAUME: [his remark is inaudible]

JORDAN: No, what I feel is that your future is what you make it.

GUILLAUME: Lucky you!

FAIZ: [his remark is inaudible] 
JORDAN: No, it's not a matter of having the right frame of mind ... It is too simplistic to say: 'Lucky you'!

FAIZ: Well, you are lucky.

COLINE: It's not a question of ...

JORDAN: I can't seem to make myself clear.

COLINE: It's not a matter of luck, there is a moment when [there is a hubbub of excited conversation] too much is expected from society.

JORDAN: That's it, exactly.

COLINE: And I think we are all caught in a welfare state dynamic.

JORDAN: Yes, that's it.

COLINE: When no one takes control of their own lives anymore. Whereas our parents and our grandparents, wherever they came from, immigrants and all, would arrive, would roll up their sleeves, and would try to carve out a life for themselves.

GUILLAUME: Yes, but there were job opportunities at that time. [numerous reactions]

JORDAN: No, it's not even a matter of job opportunities.

COLINE: There were job opportunities, but there were also a lot of hurdles to overcome. The opportunities were not handed to them on a plate!

FAIZ: That is not true. A few years ago, when you were a student, the people who were at university here were sure to find jobs, people would even approach students at the Hall of Residence with job offers. [He waves his hand as if to point to the employers huddled at the doors of the Hall of Residence]

JORDAN: [his voice drowning out that of the others] But way back then, when our parents came over to France for instance, they knew full well - at least some of them did - that they would be given no help, there was no safety net at the time. It is the same if you emigrate to the US today; there is no safety net over there; when you arrive there, you know you are on your own. So you start from scratch and you go ahead. Whereas in France, our problem is that we have social security, we have child benefit, so if we don't manage, provided we don't commit any [he hesitates] [criminal] acts, society will automatically roll out a safety net for us.

FAIZ: But that's simply not true. [hubbub]

JORDAN: It is true! There are social workers ... who will take care of you.

FAIZ: That's exactly what Madelin [a right-wing politician and free marketeer] keeps repeating. JORDAN: What?

FAIZ: That's what Madelin keeps repeating. It's not what it's really like in France. [laughter] JORDAN [looks hesitant].

The alliance formed between Jordan and Coline in the course of the discussion rests upon the exchange of autobiographical narratives which serve as models. These narratives - such as the immigrant's success story used in this instance - are presented as personal experiences or the experiences of close relatives. They are expressed and received in an emotional way, and are presented in such a way that they aim to disclose the truth, not just about the narrator, but also about the whole group, and beyond that, about society at large. Jessica and François try to reduce Jordan's narrative to an individual, anecdotal level. They ask: 'You are not going to tell us the story of your life, are you?' And they comment: 'Lucky you!' as he is seeking to infuse a broader meaning into it - 'I can't make myself clear,' he says. Coline concurs in this broader meaning when she butts in to back him up, by using 'they' instead of 'I', and above all, by intertwining their two stories through the evocation of their grandparents.

The mention of such narratives, recalling a personal or collective past, is the most frequently observed feature in the involvement process. They remind us of the 'testimony' that Lynn Sanders presents as a more desirable alternative to deliberation if we try to widen the scope of political discussion to 'real' people (by contrast with the abstract 'citizens' 
that theoreticians consider). ${ }^{34}$ Narratives are ways of fostering shared understanding among members of a polity. As Young emphasized, storytelling, narratives, are 'means of politicizing', because they are part of the sharing of experiences and of the process of 'consciousness-raising'. ${ }^{35}$ What our experiment shows very clearly is that the outcome depends on whether their exemplary dimension is accepted or called into question. ${ }^{36}$ This exemplary dimension, in so far as it involves admitting that you share a common historical heritage, reveals the main lines of cleavage, the main long-standing social and ideological dividing-lines that polarize opinion deep down in any society.

\section{Tension Between Cleavages and the Hierarchy of Identification}

To express one's opinion in public discussion with unknown people means taking a risk: these opinions might reveal that the others not only disagree with you, but also that their opinions are not compatible with yours, that they belong to a rival side. In this sense, the conflict-based approach clearly permits us to observe what citizens deem important enough to justify taking part in a political debate with complete strangers. Ultimately, this method enables us to account dynamically for cleavages, i.e. the dividing lines around which the discussion is structured.

For the past ten years or so, research on the ideological influences at work among French voters has revealed that the two main issues polarizing them have been authoritarianism and ethnocentrism. ${ }^{37}$ These dimensions carry such weight that they now supersede the traditional constituents of the right/left divide. Traditionally, the right/left divide used to be constructed first and foremost around opposite attitudes towards free enterprise and state intervention. Nowadays, although the economic and social divide persists, it has become much less clear-cut, following the conversion of a great many leaders of the left to the free-market economy. In any case, this divide now comes second after the one centred on authoritarianism and ethnocentrism. This ideological shift, which can be identified in other European countries as well, has gone hand in hand with a dramatic change in the French party political system, a change obviously demonstrated by the emergence of the National Front. $^{38}$

${ }^{34}$ Sanders, 'Against Deliberation', pp. 369-73.

${ }^{35}$ Iris Marion Young, Inclusion and Democracy (Oxford: Oxford University Press, 2000), p. 73.

${ }^{36}$ This echoes the role played by narratives in the interaction between the individual and the collective levels, as studied by Charles Tilly, using the notion of 'stories' (see Charles Tilly, Stories, Identities and Political Change (New York: Rowman and Littlefield, 2002)), but from a different angle, since he focuses on political mobilization, whereas we focus on belief systems and ideologies. Moreover, it also echoes the notion of 'narratives of the self' proposed by Giddens, who emphasizes the impact of reflexivity on modern individuals, cf. Antony Giddens, Modernity and Self Identity, Self and Society in the Late Modern Age (Stanford, Calif.: Stanford University Press, 1991).

37 Jean Chiche, Brigitte Le Roux, Pascal Perrineau and Henry Rouanet, 'L'Espace politique des électeurs français à la fin des années 1990', Revue française de science politique, 50 (2000), 463-87; Jean Chiche, Florence Haegel and Vincent Tiberj, 'La Fragmentation partisane', in Gérard Grunberg, Nonna Mayer and Paul M. Sniderman, eds, La Démocratie à l'épreuve (Paris: Presses de Sciences-Po, 2002), pp. 203-37. In English, see also Robert Andersen and Jocelyn Evans, 'Values, Cleavages and Party Choice in France, 1988-1995', and Gérard Grunberg and Etienne Schweisguth's Reply in French Politics, 1 (2003), 83-117; Gérard Grunberg and Etienne Schweisguth, 'French Political Space: Two, Three or Four Blocs?', and Andersen and Evans's reply in French Politics, 1 (2003), 331-54.

${ }^{38}$ Herbert Kitschelt, The Radical Right in Western Europe: A Comparative Analysis (Ann Arbor: University of Michigan Press, 1995). 
When we analyse the content of disagreement that occurs in the sensitive moments of focus-group discussions, where a latent conflict is being transformed into an overt conflict, we find only a few antagonisms (authoritarian versus permissive; republican-universalism versus multiculturalist-communitarian, free-market economy versus state intervention), which are well-known cleavages. This confirmation of well-established findings, far from coming as a disappointment to us, actually vouches for the fact that our sample, while clearly too small to pretend to be representative, is not ideologically abnormal. The confirmation is all the more welcome as the interest of our research design naturally does not lie in bringing qualitative confirmation of quantitatively well-established findings. What the analysis of these group discussions permits is an observation of the way the articulation of the different cleavages operates. In particular, the tensions generated by the authoritarian versus permissive cleavage cut on the republican-universalist versus multiculturalist-communitarian cleavage are quite perceptible in the discussions. In quantitative surveys, the two dimensions are regarded as part of one and the same cleavage, and yet, after analysing focus groups, it becomes apparent that their superimposition gives rise to significant tensions.

In the group of unskilled workers, the solidarity between the participants, born from a shared first-hand experience of discrimination and police profiling, is seriously threatened by their profound disagreement over ethical choices or attitudes to authority. Mansour, a participant of African origin, finds himself in a particularly difficult position. He takes sides with the most permissive members of the group when it comes to denouncing the mechanisms of discrimination; but he appears more and more embarrassed as the discussion proceeds, for when Manuel, and to a lesser degree Khaled, boast of indulging in illegal practices, this runs counter to his own moral standards and his own authoritarian cultural background. At a certain point, the discussion turns on racially-motivated identity checks. Manuel reports a conversation he has had with police officers who were checking his identity. Mansour butts in to explain that the reason why Manuel's identity was checked was because of the way he dresses. Manuel is wearing a bandana, an earring; his appearance is typically that of youngsters from the deprived suburbs. Mansour tells him: 'It's no wonder: seeing the way you dress, they are bound to put you in the same bag as me.' But Manuel cuts him off and explains that he was smoking a joint. Mansour, who made it clear several times that he does not take drugs and condemns it, makes a new attempt to keep some solidarity, some common belonging with Manuel by muttering 'even if you hadn't been smoking a joint, you clearly look the part anyway!'

Similar tensions are perceptible within the group of managers. Guillaume, who turns out to be highly sensitive to the expression of ethnic and cultural differences, and is eager to denounce all forms of discrimination against coloured people, cannot reconcile his desire to side with Faiz with the latter's coming down strongly in favour of a repressive approach, claiming the right to bring up children 'the African way', i.e., using corporal punishment and strong social control - a stand that does not go down well with the representatives of 'cultural liberalism'. This tension between attitudes of tolerance, indeed of solidarity with the immigrants on the one hand, and, on the other, a rejection of the traditional authoritarian values and practices these immigrants are proud of, is a good illustration of the complex debate over these issues that polarize French opinion. ${ }^{39}$

\footnotetext{
39 What is at work here, is not a 'new racism', or a 'symbolic racism', where a change in the line of argument goes hand in hand with a persistent ostracizing of ethnic minorities; what is at work is a clash between conflicting sets of values. See Paul M. Sniderman, Thomas Piazza, Philip E. Tetlock and Ann Kendrick, 'The New Racism',
} 
After analysing these group discussions, we are left with the impression that initiating conflict requires some kind of hierarchical organization of identifications. Participants can only become involved in the discussion and engage at the risk of conflict if they are capable of making a choice between sometimes irreconcilable identifications, by selecting the one(s) that appear(s) essential to them. We are talking about choosing between identifications made in the heat of discussion. The resources mobilized are of a symbolic and emotional rather than of a rational nature and they involve a close interweaving of the individual and the collective. From the outset, sociological research has laid stress on the multiple identifications of individuals, with each belonging to different groups ${ }^{40}$ and with group affiliations that overlap, ${ }^{41}$ so that socialization occurs in a variety of ways. As opposed to the ascriptive identities of so-called traditional societies, this multiplicity of identifications - which is regarded as a distinctive feature of modern industrial societies - is on the rise, due to the growing division of labour and mostly to an increased social and geographical mobility, at both the individual and collective levels. In fact, our experiment facilitates the observation of this plurality of value systems and identifications at the level of each participant, which gives rise to these complex interactions between various cleavages. It also permits us to observe how conflict requires rising above this complexity and how it presupposes that participants are capable, at a given moment, of making a choice between different identifications and of taking sides. In fact, it proceeds in part from a disposition to sort these complex social identifications into a value-based order. Indeed, if today's homo sociologicus is characterized by the multiplicity of his or her social roles and of his or her groups of reference, as well as of the identifications and values that result from them, ${ }^{42}$ then our experiment would seem to demonstrate that homo politicus for his or her part, can emerge only if a certain integration, or failing that, a hierarchical organization of identifications is achieved. ${ }^{43}$

\section{The Complex Interaction Between Political Competence and Conflict Involvement}

We discussed in the preceding section how latent conflict turns into an overt one by analysing the resources that lead participants to assume their differences of opinion. The social characteristics of group members have contradictory effects on this process: participants need to be able to assess the implications of others' opinions and to feel confident enough to take the risk of expressing their own views, capacities that are strengthened by higher social status; but too much cognitive competence may dilute conflict. Basically, as Carl Schmitt says, 'people do not face each other as abstractions': they get involved in an open conflict when they can get support from others; this support is garnered by giving something of themselves, something personal, some biographical elements which can be shared as a common experience or memory. This process apparently requires from participants a certain capacity to choose between one's identifications. But

(F'note continued)

American Journal of Political Science, 35 (1991), 423-47; J. B. MacConahay and J. C. Hough, 'Symbolic Racism', Journal of Social Issues, 32 (1976), 23-45.

${ }^{40}$ Maurice Halbwachs, Les Cadres sociaux de la mémoire (Paris: Albin Michel, 1994 [1925]).

${ }^{41}$ Simmel, Conflict and the Web of Group Affiliations.

${ }^{42}$ Bernard Lahire, L'Homme pluriel: les ressorts de l'action (Paris: Nathan, 1998).

${ }^{43}$ Further development of this hypothesis is to be found in S. Duchesne and V. Scherrer, 'L'Identite politique comme force de combinaison et de conflictualisation des appartenances sociales: justification théorique d'une définition empirique', in Identité(s), Actes du colloque de la MSHS de Poitiers, Presses Universitaires de Rennes, 2003, pp. 325-36, < http://erg.politics.ox.ac.uk/duchesne.asp > . 
does the fact that someone is or is not politically competent ${ }^{44}$ make any difference in his or her disposition to contribute to an open conflict?

We know from a short questionnaire filled in by the participants at the end of each session that some of them do take an interest in politics. ${ }^{45}$ However, in the course of the discussions, nobody directly voiced his own preferences or displayed his knowledge of political matters. Apparently, it is less embarrassing to confess to complete strangers, in front of a camera, that you have stolen a moped or that you smoke pot, than to publicly declare where you stand politically. Explicit references to political players (members of government, political parties, elected officials, etc.) were extremely rare. ${ }^{46}$ What is more, identifying the ideological systems that may inspire the views expressed and/or upheld by the participants is no easy task. To identify them, the words they use appear less reliable than the way people argue. Words with ideological overtones undoubtedly indicate that the participant is conversant with politics, but it does not mean that he adheres to a fully-fledged ideology. The use of the word 'capitalism', for instance, is not a reliable indicator that the participant's views are structured along strong ideological lines, for it does not predict the opinions that will influence his involvement at other stages of the discussion. Taking together all the interventions of a participant rather suggests that most people tend to cobble together disparate elements taken sometimes from similar, sometimes from different ideological systems. ${ }^{47}$ In a few cases, however, there is evidence that some participants have a strong ideological structure as well as a good command of specialized political categories at their disposal. This is not apparent, as might be expected, from their speaking more than the others. Indeed, it is not because a person seems to have great political competence that he will monopolize the conversation and impose his views on others. In these groups, what characterizes the participants with a high degree of political competence is rather their ability to encode and decode people's words politically, in other words, to read accurately, into what is being said by others, implications or consequences that far exceed the content of those words.

François (managers' group) is the best illustration of this type of attitude. He stayed in the background all through the three hours discussion, while clearly keeping track of the conversation. The few words he volunteered during the final sequence are a case in point. To one participant, who complained about those youngsters who mess up the Metro with graffiti and tags and who should be reprimanded, he retorted that these youngsters might well counter by denouncing in turn all those advertisements that debase women and are

\footnotetext{
44 The notion of 'political competence' used by Bourdieu is quite close to what American speakers call 'political sophistication', but it refers not only to the objective ability to gain command of the specialized knowledge necessary for players in party-political and electoral competition (political know-how and full command of the classification schemes of the political scene), but also to the subjective feeling that one is fully entitled to have one's say in political matters (Pierre Bourdieu, 'L'Opinion publique n'existe pas', Les Temps Modernes, 378 (1973), 1292-309; Pierre Bourdieu, 'Public Opinion Does Not Exist', in Sociology in Question (London: Sage, 1993).

${ }_{45}$ The participants' interest in politics was as follows: managers (total, 7) - a lot, 5; a little, 2; office workers (total, 7) - a lot, 3; a little, 3; not at all, 1; unskilled workers (total, 6) - a lot, 1; a little, 3; not at all, 2.

${ }^{46}$ In all the interviews, only three mentions of political professionals are to be found, and they are all prominent ones: there is one mention of Alain Madelin, a right-wing leader and staunch free marketeer; one mention of Bernard Tapie, a business man who went into politics under François Mitterrand's second presidential mandate and was implicated in corruption scandals; and one mention of Dominique Strauss-Kahn, former socialist finance minister, noting that he had been elected on a very low voter turnout at the polls.

${ }^{47}$ Billig, Ideology and Opinions; Elizabeth Frazer, 'Teenage Girls Reading Jackie', Media, Culture and Society, 9 (1987), 407-25.
} 
more shocking than graffiti. When a participant of African descent said that to maintain law and order, you have to speak the right language, i.e. the one spoken in African villages, François concluded that the police should recruit more immigrants. Lastly, when the discussion revolved around how ordinary citizens can participate in the fight against delinquency, he spoke again to say that to begin with, people should not send their children to private schools, and should not become obsessed with law and order. These examples make plain that François adheres to a well-structured belief system. Unlike other participants, he intervenes but rarely, and not really to add to, support or back up what has just been said or to ally himself with others and, by so doing, contribute to introducing conflict in the discussion. Rather, he is always slightly ahead of the others. His remarks always tend to shift the conversation to other subjects - in so far that is, that others follow him on to this new ground, which is seldom the case.

François did not get support from others nor make alliances with them. Moreover, he never offered arguments taken from his personal experience: his points always refer to external evidence. Different elements may contribute to explain his attitude. First, Francois was the only one in the group who was not unemployed: he applied for the discussion because he was interested but actually had a job. This may have distanced him from the others more than we might suppose. Secondly, the arguments he used in the discussion may be too sophisticated and implicit for the others who are obviously less politically competent and may have missed the point. Lastly, his political competence may have caused a different attitude towards discussion which elicits conflict but lacks personal involvement.

So participation in overt conflict is not necessarily reinforced by political competence, although it may be, as in the case of Faiz. Faiz is a manager of Chadian descent. In the course of the discussion, he discloses the fact that he trained in a communist country to be an engineer. Obviously, he has strong ideological commitments, as shown by his ability to decode other people's words, as well as by his competitive, not to say contentious, attitude, complete with an apparent total lack of self-doubt and an eagerness to bring others round to his point of view. Faiz's behaviour singles him out, by the consistency and single-mindedness of his remarks, as well as their purpose. Each of his interventions is actually an attempt to tackle the issue under discussion from a new angle of his own. Unlike François, Faiz occasionally gets involved in the discussion and exposes himself by disclosing personal details. This is the case when, in a very emotional way, he mentions that his daughter is becoming discouraged from going on with her studies by the fact that both her parents, though highly-qualified, cannot find jobs on account of their ethnic origin.

In a previous work, based on individual interviews, ${ }^{48}$ we have underlined the fact that one can be politically competent without becoming involved: competence does not necessarily cause people to take sides and clearly stand for the cleavages that are most important to them. These experimental focus groups suggest some hypotheses which can explain this quite complex relationship between political competence and involvement in public discussion. Political competence gives a participant the ability to understand easily which conflicts are at stake in the discussion and the confidence to induce conflict. But, as shown empirically by these focus groups, the expression of political competence is not sufficient (and might even sometimes seem counter-productive) to rally others to one's side

${ }^{48}$ Duchesne and Haegel, 'Entretiens dans la cité'. 
and to make conflicts overt. To do so, participants must look for others' support; and getting support requires exposing oneself personally by disclosing elements of one's own (or one's relative's) life to which others can relate.

\section{CONCLUSION}

Our experiment was carried out only in France and we have left aside the question of the transferability of the hypotheses, as we are aware of the French political specificity. In many respects, France is by no means unique, since dwindling trust in political institutions, ${ }^{49}$ a rising abstention rate ${ }^{50}$ and massive changes in political commitment ${ }^{51}$ are to be observed in other countries as well. However, conflict has been considered as the main feature of French culture and of the French political system. Historically, the prominent place of conflicts in French society along with the ambivalent attitude of the French towards authority, which they both revere and challenge, have long been highlighted by a great many English-speaking specialists of French politics. ${ }^{52}$ The French political system is characterized by a high degree of polarization ${ }^{53}$ and by the existence of political parties at the far ends of the political spectrum. ${ }^{54}$ This may explain why study of the French political system has led us 'as a matter of course' to place conflict at the heart of our theoretical and empirical design. The next step of this research programme is therefore putting the validity of our approach to the test in other societies that are not traditionally characterized as contentious, in particular, British society and that of the French-speaking part of Belgium. However, we would like to conclude by emphasizing three main possible consequences of our findings.

First, in our research, the conflict-based approach did not lead us to identify conflict everywhere in discussions. On the contrary, we observe that conflict generally remains latent and that assuming conflict in public requires specific conditions and processes. For the individuals, politicization is demanding, it is a process of involvement and cannot be taken for granted. However, in academic literature as well as in public debates, it is often

49 Etienne Schweisguth, 'La Dépolitisation en questions', in Grunberg, Mayer and Sniderman, eds, La Démocratie à l'épreuve, pp. 50-86; Pippa Norris ed., Critical Citizens: Global Support for Democratic Governance (Oxford: Oxford University Press, 1999); Joseph S. Nye, Philip H. Zelikow and David C. King, eds, Why People Don't Trust Government (Cambridge, Mass.: Harvard University Press, 1997).

${ }^{50}$ Anne Muxel and Jérôme Jaffré, 'S'Abstenir: hors du jeu ou dans le jeu politique?' in P. Bréchon, A. Laurent and P. Perrineau, eds, Les Cultures politiques des Français (Paris: Presses de Science Po, 2000), pp. 19-52; Mark N. Franklin, Voter Turnout and the Dynamics of Electoral Competition in Established Democracies since 1945 (Cambridge: Cambridge University Press, 2004).

51 Pascal Perrineau, ed., L'Engagement politique: déclin ou mutation? (Paris: Presses de Sciences Po, 1994); Isabelle Sommier, Le Renouveau des mouvements contestataires à l'heure de la mondialisation (Paris: Flammarion, 2003); Russel J. Dalton and Martin P. Wattenberg, eds, Parties Without Partisans: Political Change in Advanced Industrial Democracies (Oxford: Oxford University Press, 2000).

52 Stanley Hoffman et al., In Search of France (Cambridge, Mass.: Harvard University Press, 1963); Charles Tilly, The Contentious French (Cambridge, Mass.: Harvard University Press, 1986); William Schonfeld, Obedience and Revolt: French Behaviour Towards Authority (Beverly Hills, Calif.: Sage, 1976); Theodore Zeldin, Politics and Anger (Oxford: Oxford University Press, 1979).

${ }^{53}$ Giovani Sartori, 'European Political Parties: The Case of Polarized Pluralism', in Joseph Palombara and Myron Werner, eds, Political Parties and Political Development (Princeton, N.J.: Princeton University Press, 1966), pp. 137-76.

${ }^{54}$ For a long time, political conflicts were fuelled by the existence of a strong Communist Party in conjunction with strong anti-communist feelings, but this antagonism has lost much of its virulence, following the decline of the French Communist Party. Currently, however, the fact that the far-right National Front has taken root is nurturing a different kind of ideological and partisan polarization. 
suggested that depoliticization puts democracy at risk. The explanations or supposed causes of depoliticization are manifold. Nina Eliasoph, in her brilliant work, insists on the evaporation of the political in American society. She supposes that the anthropological process of politicization is prevented by American culture and institutions. We agree that there are constraints on the politicization process; but we also think that this would not be enough to suppress them: politicization has to be voluntarily produced. Improving political involvement requires a specific or even a creative effort.

Secondly, we address the question of the quite complex relationship between political competence and politicization in public discussion. In our study, personal involvement is the necessary condition for politicization. Political competence is not directly related to political involvement; it does not necessarily cause people to take sides. Personal involvement does require the capacity to organize or at least to prioritize one's affiliations and identifications. This result matches the situation of contemporary Western societies, where people are more and more educated and hence politically competent, where affiliation and identification systems are more and more fragmented, and where citizens are suspected of distancing themselves more and more from politics.

Lastly, let us come back to the debate between a conflict-based approach and a deliberative model of democracy. The theoretical debate about deliberative democracy has re-emphasized the role of political discussion in the democratic system: everyday talk is assigned a central role in the deliberative process. ${ }^{55}$ This refocusing of the study of political discussion changes expectations about it. Our experimentation reveals at least that a deliberative model is not sufficient to account for what is at stake in public discussions. Political discussion not only gives rise to an exchange of opinions aiming at understanding each other's point of view and reaching consensus; it also produces expressions of disagreement, which sometimes coincide with durable conflict. Opinions about public questions, about topics that are potentially of interest for a large portion of society, are not only ideas: they are also signs, markers, which tell others which groups one belongs to.

\section{APPENDIX: INTERVIEW SCENARIO}

9.45: Opening question: 'What does delinquency mean to you?' (The participants answer orally and publicly and the facilitator writes down their answers on a flipchart.)

10.15: Question to be answered in writing: 'How come some people drift into delinquency?' The participants are divided into two or three groups and are given 25 minutes to note down their answers on a few cards which are subsequently stuck up on the notice-board and discussed by the whole group.

11.05: Benchmark question: 'What are the three factors/causes about which you feel something should be done?' Each participant is given three coloured sticky labels to be stuck next to the answers (s)he has selected.

11.15: Break

11.30: The three groups are requested to complete a scenario: for the group of managers and the group of unskilled workers, the script reads as follows: "A couple who are just coming out of a hypermarket are requested by a security guard to open their bags for inspection; he sees that they have stolen a mobile phone. What do you think happens next? Who are the various protagonists in the story? Who is involved/concerned? Who should intervene? What should be done?'

For the group of office workers, the script reads as follows: 'An old lady has her handbag snatched from her by two youths riding a moped.' Same set of questions.

11.45: The group is divided into two subgroups; each subgroup elaborates a scenario.

55 Jane Mansbridge, 'Everyday Talk in the Deliberative System', in Macedo, Deliberative Politics, pp. 211-39. 
12.15: Presentation of the first scenario.

12.30: Presentation of the second scenario.

12.45: Theory up for discussion: 'There is not much the average man or woman in the street can do to fight against delinquency.' Each participant casts his/her vote on the theory written on the notice-board, by using ,,,+++- or -- signs, then the votes are commented upon. 